\title{
Oil Pollution in Indonesian Waters: Combining Statistical Analyses of ENVISAT ASAR and Sentinel-1A C-SAR Data With Numerical Tracer Modelling
}

\author{
Martin Gade ${ }^{1 *}$, Bernhard Mayer ${ }^{1}$, Carolin Meier ${ }^{1}$, Thomas Pohlmann ${ }^{1}$, Mutiara Putri ${ }^{2}$, and Agus Setiawan ${ }^{3}$ \\ ${ }^{1}$ Institut für Meereskunde, Universität Hamburg, 20146 Hamburg, Germany - Martin.Gade@ uni-hamburg.de \\ ${ }^{2}$ Institute Technology Bandung, Bandung, Indonesia \\ ${ }^{3}$ Agency for Marine and Fisheries Research and Development, Jakarta, Indonesia
}

KEYWORDS: Marine oil pollution, Indonesian waters, monsoon, numerical tracer model, SAR, oil spill detection

\begin{abstract}
:
This Pilot Study aimed at improving the information on the state of the Indonesian marine environment that is gained from satellite data. More than 2000 historical and actual synthetic aperture radar (SAR) data from ENVISAT ASAR and Sentinel-1A/B C-SAR, respectively, were used to produce oil pollution density maps of two regions of interest (ROI) in Indonesian waters. The normalized spill number and the normalized mean polluted area were calculated, and our findings indicate that in general, the marine oil pollution in both ROI is of different origin: while ship traffic appears to be the main source in the Java Sea, oil production industry causes the highest pollution rates in the Strait of Makassar. In most cases hot spots of marine oil pollution were found in the open sea, and the largest number of oil spills in the Java Sea was found from March to May and from September to December, i.e., during the transition from the north-west monsoon to the south-east monsoon, and vice versa. This is when the overall wind and current patterns change, thereby making oil pollution detection with SAR sensors easier. In support of our SAR image analyses high-resolution numerical forward and backward tracer experiments were performed. Using the previously gained information we identify strongly affected coastal areas (with most oil pollution being driven onshore), but also sensitive parts of major ship traffic lanes (where any oil pollution is likely to be driven into marine protected areas). Our results demonstrate the feasibility of our approach, to combine numerical tracer modelling with (visual) SAR image analyses for an assessment of the marine environment in Indonesian waters, and they help in better understanding the observed seasonality.
\end{abstract}

\section{INTRODUCTION}

Indonesian territorial waters cover about three million square kilometers and are home to more than 3.000 species of fish and more than 500 species of corals. The Indonesian coastline is longer than 80.000 kilometers, and the Indonesian archipelago encompasses more than 17.000 islands. Major ship traffic routes, connecting the economic centers on the South China Sea (and beyond) with Europe, Africa, Australia, or the Persian Gulf, run through Indonesian waters.

Although its total oil production has decreased by $25 \%$ during the past decade, Indonesia still ranks amongst the top 25 oil producing countries worldwide and is the third-largest oil producer in Pacific Asia (BP, 2014). However, not only because of a continuously increasing demand Indonesia, along with its neighboring countries, has always been importing oil from other countries worldwide.

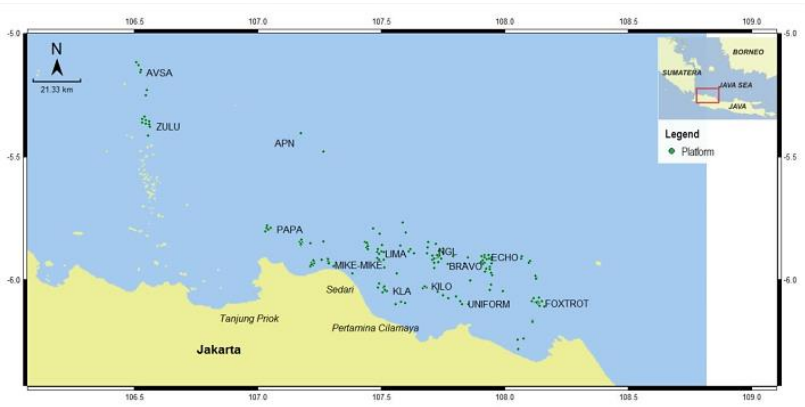

Figure 1. Locations of oil production fields in the south-western Java Sea.
The marine ecosystem in Indonesia is under increasing pressure due to social and economic growth in the entire region. Parts of the so-called Coral Triangle, a six million square kilometers area in Pacific Asia, lie in Indonesian territorial waters, where the coral reef area is estimated to be 20,000 square kilometers in size (Figure 2). Along with mangrove forests and seagrass meadows on the coasts, these areas are particularly vulnerable to pollutants.

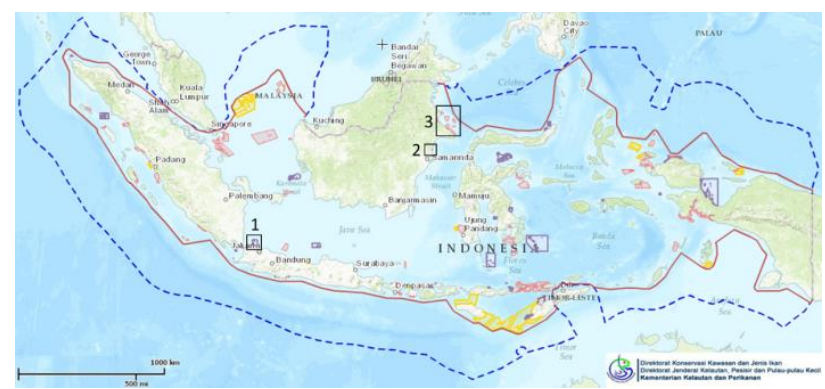

Figure 2. Marine Protected Areas (MPA) in Indonesia. The red line marks the territorial border, the dashed blue line the EEZ.

The color of the MPA (hatched areas) denotes the national responsibility. Three MPA are marked by black rectangles: 1 :

'Seribu Islands'; 2: 'South Bontang'; 3: 'Berau'.

Several marine protected areas (MPA) have been defined in Indonesia, where part or the entire enclosed environment is protected by law or other effective means (Figure 2). Continuous monitoring is of key importance in these areas, but can only be done in an effective manner by taking advantage of state-of-the-art remote sensing and numerical modelling techniques. The goal of this Pilot Study was to combine spaceborne remote sensing data with sophisticated numerical models to meet these monitoring requirements.

\footnotetext{
* Corresponding author
} 
The joint German-Indonesian Pilot Study IndoNACE (Indonesian seas Numerical Assessment of the Coastal Environment) aimed at improving the information on the state of the Indonesian marine environment that can be gained from satellite data. Synthetic aperture radar (SAR) data were used to produce oil pollution density maps of two dedicated regions of interest (ROI) in Indonesian waters, namely the Western Java Sea and the Strait of Makassar (Figure 4). Our results presented herein complement those presented earlier (Gade et al., 2016).

Marine mineral oil spills show up on SAR imagery as dark patches (Gade, 2006; Gade and Alpers, 1999), which however can be confused with other, atmospheric or oceanic, phenomena such as wind shadowing, biogenic slicks, etc. (Brekke and Solberg, 2005). Since (the development of) an automated oilpollution detection system was not in the scope of this study, a visual inspection of all available SAR images of Indonesian waters was performed, along with a manual registration in stateof-the-art databases including geo-information on the detected spills (lat/lon, size, etc.) and metadata (wind speed and direction, etc.). Special emphasis was put on the discrimination between anthropogenic (mineral oil) spills and biogenic slicks, since both species tend to cause similar features on SAR imagery (Gade et al., 1998, 2013).

Both historical and actual SAR data from ESA's ENVISAT archive and Sentinel 1A/B Rolling Archive were used. An example of frequent oil pollution due to offshore oil production is shown in Figure 3: five excerpts from Sentinel-1A SAR images of the ROI ' $W$ Java Sea' show dark patches linked to a bright spot at coordinates $5^{\circ} 54^{\prime} 42^{\prime}$ 'S $107^{\circ} 55^{\prime} 35^{\prime \prime} \mathrm{E}$. This is an oil rig in the 'ECHO' oil field (Figure 1), from which oil is frequently released. Note that in different seasons, the varying currents cause an oil drift into different directions. Such findings have been used as input for the numerical modelling and as validation of the model results.
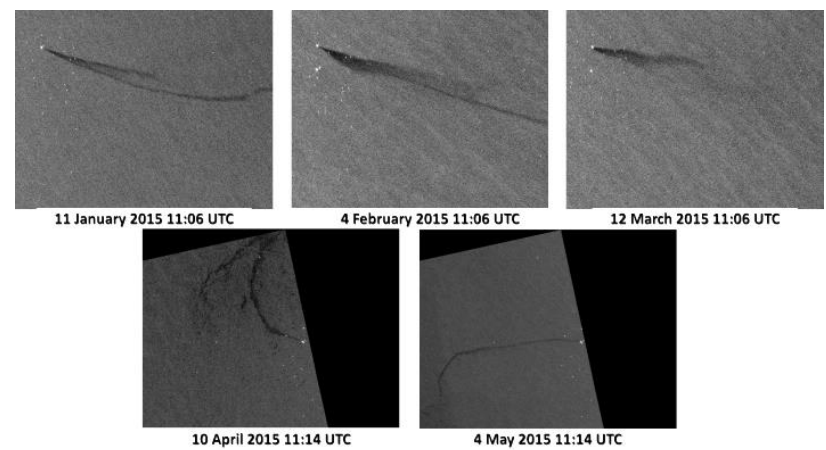

Figure 3. Case study of frequent oil pollution caused by offshore oil industry. The bright spot, from which the dark patches in all panels origin, is an oil rig off Java, at $5^{\circ} 54^{\prime} 42^{\prime \prime} \mathrm{S}$ $107^{\circ} 55^{\prime} 35^{\prime \prime} \mathrm{E}$.

\section{REGIONS OF INTEREST}

The aim of this study was to gain information on, and to further the knowledge about, the vulnerability of dedicated marine (coastal and offshore) areas in Indonesia to marine oil pollution. Two ROI had been identified (Figure 4), the western part of the Java Sea, with borders $105.0^{\circ} \mathrm{E}-111.0^{\circ} \mathrm{E}$ and $7.0^{\circ} \mathrm{S}-3.0^{\circ} \mathrm{S}$, and the Makassar Strait, with borders $116.0^{\circ} \mathrm{E}-120.0^{\circ} \mathrm{E}$ and $5.5^{\circ} \mathrm{S}-1.0^{\circ} \mathrm{N}$. They were chosen because of high economical activities (including ship traffic) and a high density of MPA and coral reefs, respectively. Oil pollution density maps were produced for both areas and, along with sensitivity charts of coastal areas, were used as input for numerical modelling activities. The ultimate goal of this effort was to provide qualitative and quantitative information on the way, in which marine oil pollution presents a hazard to particularly sensitive coastal regions.

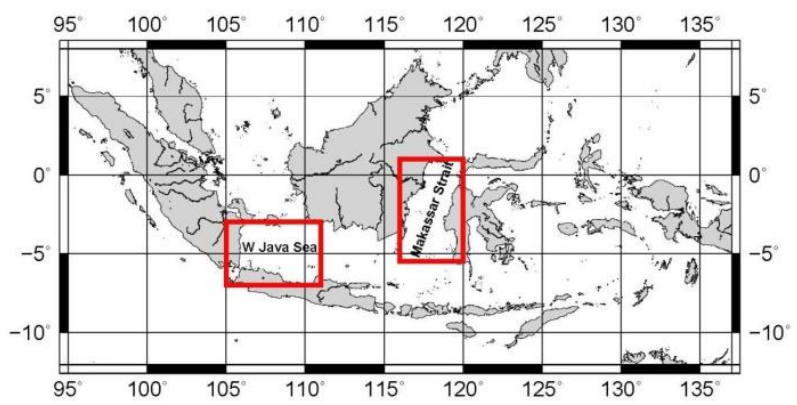

Figure 4. Two regions of interest (ROI): "W Java Sea" with borders $105.0^{\circ} \mathrm{E} / 111.0^{\circ} \mathrm{E}$ and $7.0^{\circ} \mathrm{S} / 3.0^{\circ} \mathrm{S}$, and "Makassar Strait" with borders $116.0^{\circ} \mathrm{E} / 120.0^{\circ} \mathrm{E}$ and $5.5^{\circ} \mathrm{S} / 1.0^{\circ} \mathrm{N}$.

\section{SAR DATA}

In total, more than 5000 SAR images were available for our statistical analyses, acquired by ENVISAT ASAR (more than 1600, acquired 2002-2012), ALOS-1 PALSAR (more than 2800, acquired 2006-2011), and Sentinel-1A (almost 800, acquired from 2014). Analyses of all SAR images were done visually by student operators, who had been thoroughly trained. Figure 5 shows the total coverage of both ROI by ENVISAT ASAR (upper panel) and Sentinel-1A/B SAR-C (lower panel) imagery, indicating that the western and south-western parts of the Java Sea were best covered, as well as the north-western and northern Makassar Strait, off the harbor of Balikpatan and to its north-east, a region of intense oil production.

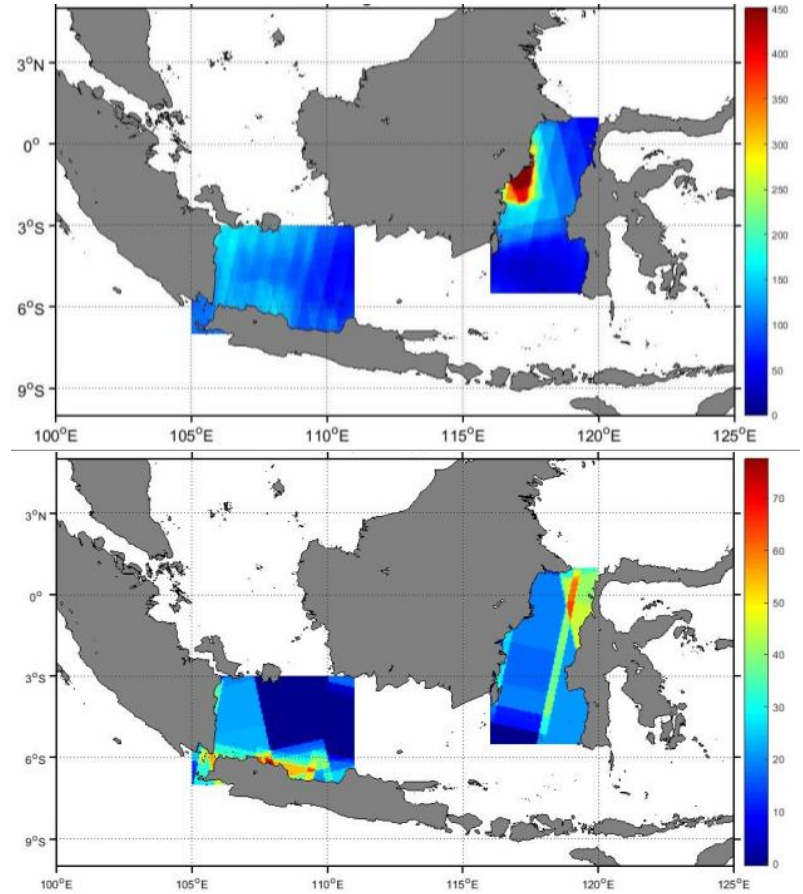

Figure 5. SAR coverage of both ROI. Upper: ENVISAT ASAR; lower: Sentinel-1A/B C-SAR.

In this paper, we concentrate on those results that were obtained through the analysis of the ENVISAT ASAR images, of which more than 700 images were acquired over the Western Java Sea and about 900 over the Makassar Strait. 

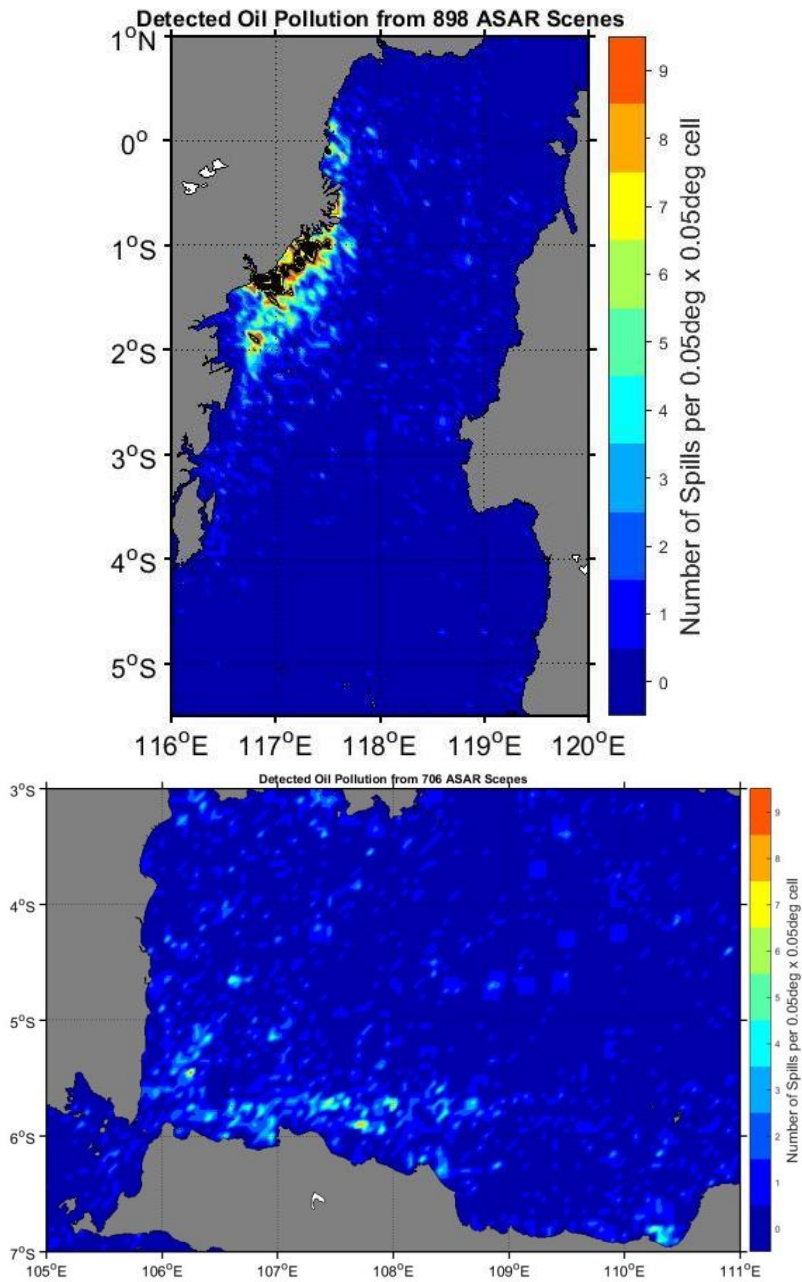

Figure 6. Number of Spills per $0.05^{\circ} \times 0.05^{\circ}$ grid cell, as detected in more than 1600 ENVISAT ASAR images of both ROI.

\subsection{SAR Image Analyses}

The geographical locations of all detected oil spills, binned into a $0.05^{\circ} \times 0.05^{\circ}$ grid, for the Western Java Sea (upper) and the Makassar Strait (lower) are shown in Figure 6. Clearly visible are areas of higher oil pollution north of western Java, where up to nine spills per grid cell were found, and in the Makassar Strait, off Kalimantan's coast, where the maximum number of oil spills per grid cell well exceeds 30 (for better visualisation the colour coding in both panels is the same, so that high spill numbers in the Makassar Strait, exceeding 9, appear in black). These areas are marked by high ship traffic ('W Java Sea') and by heavy oil production ('Makassar Strait'), both putting the local environment under severe threat.

A comparison with the marine traffic density in both areas (not shown herein) supports this initial assumption. In the 'W Java Sea' the oil spill density patterns (lower panel of Figure 6) can be immediately correlated with main ship traffic routes: leaving the Sunda Strait northwards, the major ship lanes split up into two, one heading north-east (towards northern destinations, e.g. in the South China Sea) and one heading east (towards Jakarta and destinations further east). Together with oil production fields north off Java (Figure 1) and the port of Semarang in the south-east of the ROI, both can be easily inferred from the lower panel of Figure 6.
The main ship traffic routes in the ROI 'Makassar Strait' are less correlated with patterns of maximum detected oil pollution (upper panel of Figure 6). Instead, most oil pollution was observed in an area of high oil production industry, off Balikpapan and further north-east, but of less ship traffic. These findings indicate that in general, the marine oil pollution in both IndoNACE ROI is of different origin. We also note, however, that the areas of maximum detected oil pollution often coincide with those areas, where the SAR image coverage is highest (Figure 5).

Taking into account the inhomogeneous spatial coverage by all available ASAR images we calculated the normalized mean polluted area in $\mathrm{km}^{2}$ as the ratio of the total spill-covered area and the SAR coverage, for simplicity derived for an amount of 100 SAR images. The normalized mean polluted area is rather independent of the heterogeneous data coverage and, given a 'critical SAR coverage' at any place in both ROI, allows quantitative comparisons and objective conclusions. Results are shown in Figure 7 , again, binned into a $0.05^{\circ} \times 0.05^{\circ}$ grid.
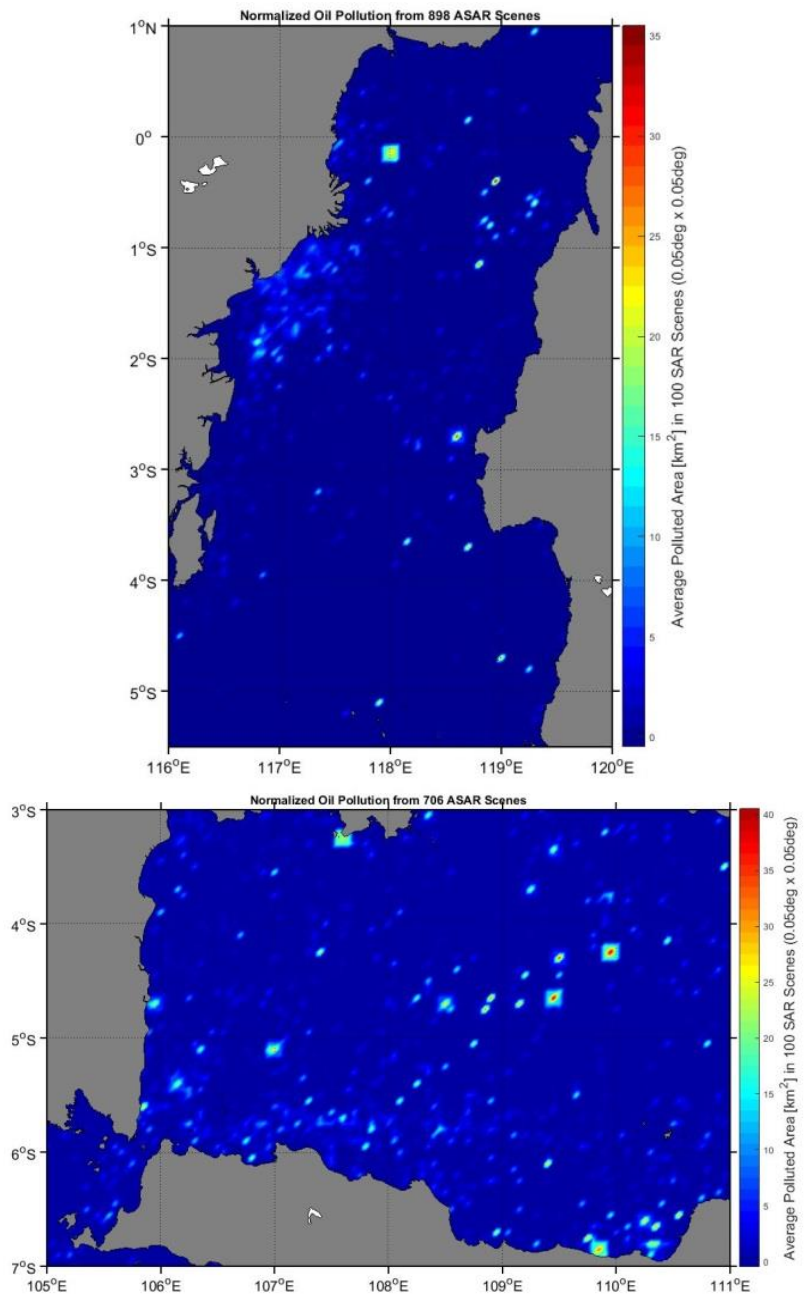

Figure 7. Normalized mean polluted area per $0.05^{\circ} \times 0.05^{\circ}$ grid cell and per 100 SAR images, as detected in approx. 1600

ENVISAT ASAR images of the two IndoNACE ROI, 'Java Sea' (lower) and 'Strait of Makassar' (upper).

It is interesting to note that, after the analysis of all available ASAR images, in most cases hot spots of marine oil pollution are found in the open sea. Moreover, local hot spots in terms of the total amount of detected oil spills (Figure 6) are no longer 
areas of highest normalized pollution (Figure 7). However, all industrial coastal areas in both ROI coincide with regions where the mean oil pollution in a $0.05^{\circ} \times 0.05^{\circ}$ grid cell exceeds $5 \mathrm{~km}^{2}$ per $100 \mathrm{SAR}$ images, i.e., $50,000 \mathrm{~m}^{2}$ per single SAR image. Statistically, the areal fraction of pollution in those areas, therefore, is at least $0.2 \%$, but can easily reach $1.5 \%$ in certain locations in the central Java Sea and open Makassar Strait. This is the fractional areal that is polluted at any time, according to our analyses of approx. 1600 ASAR scenes.

Actual SAR data from the Sentinel mission were used to complement the analyses and results presented above. Here we concentrated on the ROI 'W Java Sea', of which a total of 207 Sentinel-1A SAR images acquired in November 2014 - June 2016 (20 months) were analyzed. The locations and sizes of all detected oil spills are shown in Figure 8, where the circles' diameters are proportional to the spill sizes and the color coding refers to the month, in which the oil pollution was imaged by Sentinel-1A. It is obvious that most pollution was found along the coasts of Java and Sumatra; however, we also note that those are the areas that were most frequently imaged (Figure 5). While no immediate relationship between the amount of oil spills and the months of the year can be seen, the color coding indicates that less pollution was found in June/July (light green circles).

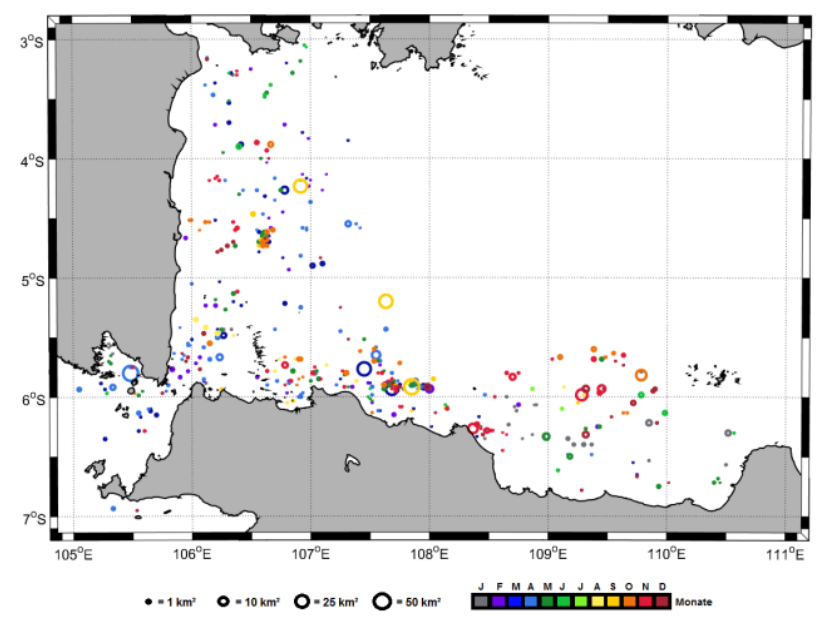

Figure 8. Map of oil pollution found on Sentinel-1A/B SAR-C imagery of the ROI 'W Java Sea'. Circle diameters are proportional to the spill sizes, and the color coding denotes the monthly distribution (Meier, 2016).

The seasonality of the observed oil pollution in the Western Java Sea is demonstrated in Figure 9. The upper panel shows the total number of oil spills detected in each month of the year (blue) and the respective total number of SAR images (black), while the lower panel shows the respective number of oil spills per SAR image of that ROI (blue).

The largest number of oil spills has been found in March - April and October - December, i.e. in periods of the transition from north-west monsoon to south-east monsoon, and vice versa. During those periods, the overall current pattern in the Java Sea changes, which can be seen in the simulated backward trajectories from the MPA 'Seribu Islands' in Figure 11. A greater amount of water from the inner Java Sea is moving towards south-west, thereby reaching those areas where the highest pollution was encountered. This example demonstrates how our approach, to combine numerical tracer modelling with (visual) SAR image analyses, can help in better understanding the observed seasonality.

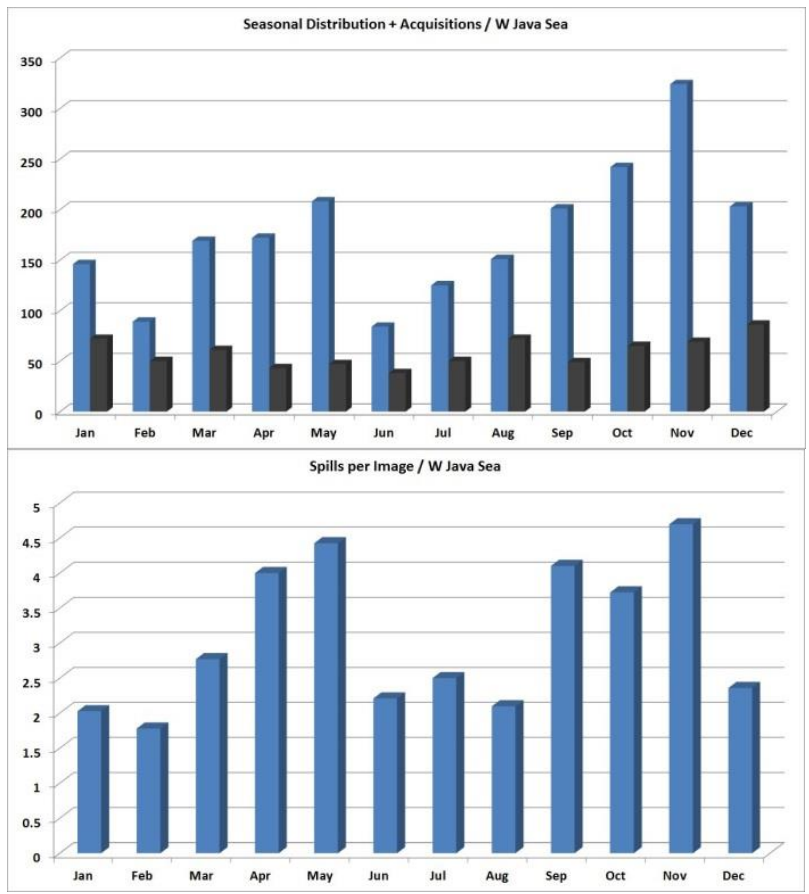

Figure 9. Seasonal variation of the detected oil pollution in the ROI 'W Java Sea'. The upper panel shows the distribution of the numbers of oil spills that were found in 130 ENVISAT

ASAR images. The lower Panel shows the respective distribution of the average numbers of oil spills per SAR image.

The corresponding results for the Makassar Strait are shown in Figure 10. Here, maximum pollution was found in December February. This is the period of the northwest monsoon, which drives additional water from the Banda Sea into the Makassar Strait, thereby slowing down the overall current speed.
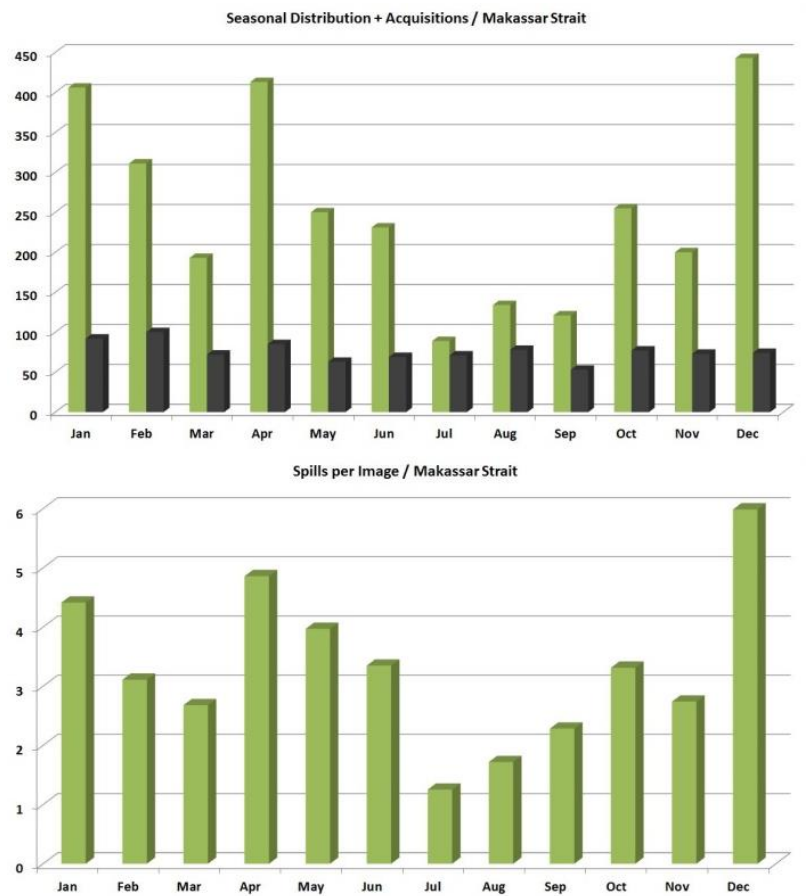

Figure 10. Same as Figure 9, but for the ROI 'Makassar Strait'. 


\section{NUMERICAL MODEL}

The meso-scale Hamburg Shelf-Ocean Model, HAMSOM, (Backhaus, 1985; Mayer and Damm, 2012) was employed covering the entire Indonesian waters at a horizontal resolution of $6 \mathrm{~nm}$ (approx. $11 \mathrm{~km}$ ). The water depth is divided into 39 layers with thicknesses ranging from $5 \mathrm{~m}$ in the first layer to $550 \mathrm{~m}$ in deeper areas. Open boundary values were provided by the global ocean model MPI-OM (Jungclaus et al., 2013), guaranteeing that open boundary information and far-field signals entering the regional model domain can be adequately considered. The hydrodynamic model is forced by meteorological parameters, seawater temperature and salinity and sea level from the global model (Mayer et. al., 2015). Model results were validated using observed velocities from moored current meters of the INSTANT project (Sprintall et al., 2009) at different locations, as well as SST and SSS satellite data.

The subsequently applied model is a Lagrangian tracer model (Mayer, 1995), which uses the simulated velocities of HAMSOM. According to its location within a grid cell the tracer is subject to the spatially interpolated velocity including its acceleration along its path due to spatial change of the velocities. This is done for the horizontal direction only, because the oil spills are tracked only as long as they move horizontally on the sea surface. The simulation was performed in a backward direction for four weeks in four typical months in the period 2003-2011: end to beginning of February (fully developed NW monsoon), of April (transition period), of August (fully developed SE monsoon) and of October (transition period). Tracers were released into every grid cell located within the coordinates of the three MPA.

\subsection{Modelling Results}

Simulation results for the backward trajectories are presented in Figure 11 and Figure 12. They were calculated with daily averaged velocities for the years 2003-2011. Particles were released on the last day of the months February, April, August and October in each year into the model grid boxes in the areas of the MPA in Seribu Islands (Figure 11) and Bontang and Berau (Figure 12). The chosen months represent fully developed NW monsoon, transition period, fully developed SE monsoon and transition period, respectively. Different colors correspond to different years, as indicated by the legend. Diamonds mark the positions a week away from the MPA.

For the Seribu Islands MPA (Figure 11), only the August trajectories show a uniform distribution of the tracer paths, indicating that oil spills detected in the Seribu MPA most probably originate from east, regardless of the year. The possible source is located within an area of approx. $110 \mathrm{~km}$ (north-south) and $400 \mathrm{~km}$ (west-east) along the northern coast of Java. During the SE monsoon season, the quite strong surface currents in the Java Sea are clearly directed westward. In contrast, during NW monsoon season (February), the direction is opposite with much weaker currents. The area of possible sources of oil in the ocean covers approx. $110 \mathrm{~km}$ (north-south) and $200 \mathrm{~km}$ (west-east). Only in 2003, the tracers came through the Sunda Strait from the Indian Ocean, and only for three years, the origin might have been around Bangka Island, almost $400 \mathrm{~km}$ north of Seribu Islands. Both transition periods April and October show year-dependent wide-spread possible origins in a large area to the north and east of Seribu Islands, which can be explained by a yearly varying transition period.
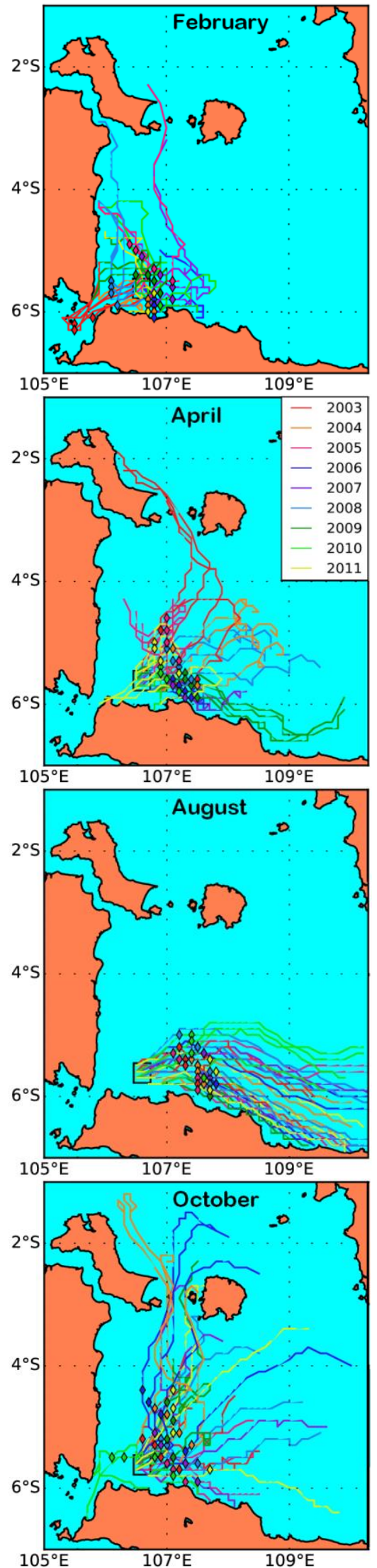

Figure 11. Simulated backward trajectories of tracers starting in the MPA "Seribu Islands", western Java Sea. Different colors show different years, different panels show different months.

The diamonds show the position after one week backward simulation, i.e. one week before they would arrive at the MPA. 

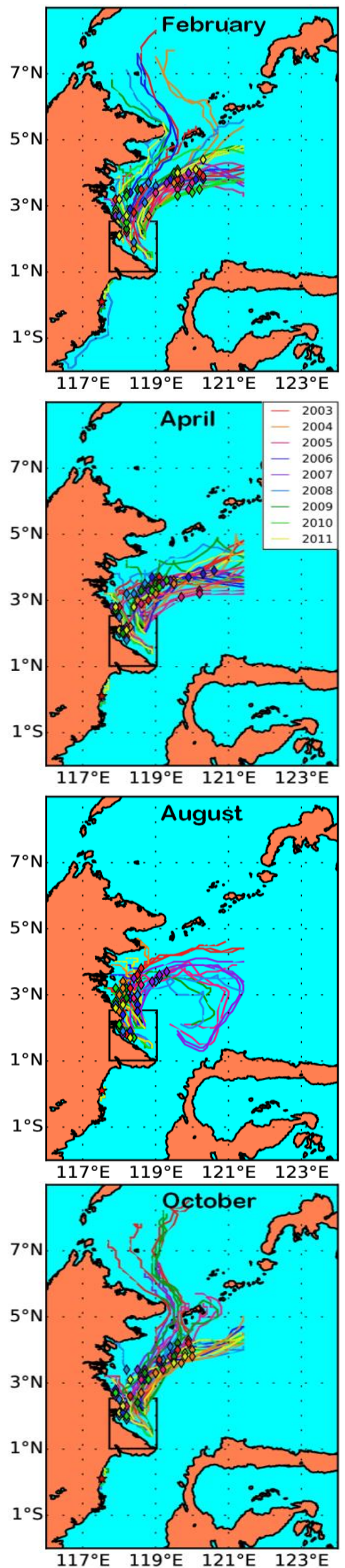

Figure 12. Same as Figure 11, but for the MPA "Berau", northwest of Makassar Strait entrance (marked by a black rectangle), and "Bontang" in the northwestern Makassar Strait (marked by a red star).
For the Berau MPA (black rectangle in all panels of Figure 12), the oil spills originate always in the north to north east of the MPA, showing the general counter-clockwise circulation in the Celebes Sea. Only for February and October, oil spills might be transported even from the Sulu Sea towards the Berau MPA. Trajectories east of $121.5^{\circ} \mathrm{E}$ were truncated because of the end of the tracer model grid. In a forward view, tracers starting at this longitude would arrive at the MPA after approx. 9-14 days in all months and all years. In the August panel, a large eddy is obvious for three years. This is the result of eddy shedding processes of the Mindanao Current, of which the reflection zone south of the Philippines back to the NECC (North Equatorial Counter Current) moves more and more into the Celebes Sea. After shedding, the eddy moves westward in the Celebes Sea towards the northern entrance to the Makassar Strait.

The Bontang MPA (red star in all panels of Figure 12) tracers show hardly any movement, because they are too close to the coast, were the currents are obviously very slow.

\section{CONCLUSIONS}

Historical and actual SAR data from ESA's ENVISAT archive and Sentinel 1A Rolling Archive, respectively, were used for the generation of pollution occurrence maps that include all detected oil pollution. SAR images of the two ROI were visually inspected, while special emphasis was put on the discrimination between anthropogenic (mineral oil) spills and biogenic slicks, since both species tend to cause similar features on SAR imagery. The crude statistical charts were further improved by including information on the SAR coverage and local weather conditions (basically the wind speed, which is the limiting factor for the visibility of oil pollution on SAR imagery). As a result improved pollution density maps of both ROI were generated and will be kept up-to-date through the continuous inclusion of actual SAR data.

In parallel, an existing numerical model was adapted and, in combination with a tracer dispersion model, high-resolution numerical backward tracer experiments were performed. Choosing dedicated MPA as starting point for backward tracing modelling exercises, we were able to show that potential areas, from any marine pollution of the MPA could originate, differ depending on the season and, therefore, on the overall wind conditions (winter and summer monsoon).

Our crude statistical charts will be further improved by including information on the local SAR coverage and local weather conditions (basically the wind speed, which is the limiting factor for the visibility of oil pollution on SAR imagery). Further studies will also include forward tracer modelling, starting from those areas, in which the strongest marine pollution was found, i.e. using the previously gained information sets on existing pollution as input. Thereby we will identify strongly affected coastal areas (with most oil pollution being driven onshore), but also sensitive parts of major ship traffic lanes (where any oil pollution is likely to be driven into Marine Protected Areas).

\section{ACKNOWLEDGEMENTS}

The pilot study IndoNACE received funding from the European Space Agency (ESA) under contract ITT AO 18176/14/F/MOS. ENVISAT ASAR imagery was kindly made available by ESA's EO Grid Processing On-Demand (EOGPOD) Team. 


\section{REFERENCES}

Backhaus, J. O., 1985. A three-dimensional model for the simulation of shelf sea dynamics. Deutsche Hydrographische Zeitschrift, 38 , pp. 165-187.

BP, 2014. BP Statistical Review of World Energy June 2014, http://www.bp.com/content/dam/bp/pdf/Energy-economics/ statistical-review-2014/BP-statistical-review-of-world-energy2014-full-report.pdf (10 Feb '15).

Brekke, C., and A.H.S. Solberg, 2005. Oil spill detection by satellite remote sensing. Remote Sensing of the Environment., 95, pp. 1-13.

Gade, M., 2006. On the imaging of biogenic and anthropogenic surface films on the sea by radar sensors, in Marine Surface Films: Chemical Characteristics, Influence on Air-Sea Interactions and Remote Sensing, M. Gade, H. Hühnerfuss, and G.M. Korenowski (Eds.), Springer, Heidelberg, pp. 189-204.

Gade, M., and W. Alpers, 1999. Using ERS-2 SAR images for routine observation of marine pollution in European coastal waters, Science of the Total Environment, 237-238, pp. 441448 .

Gade, M., W. Alpers, H. Hühnerfuss, H. Masuko, and T. Kobayashi, 1998. The imaging of biogenic and anthropogenic surface films by a multi-frequency multi-polarization synthetic aperture radar measured during the SIR-C/X-SAR missions, Journal of Geophysical Research, 103, pp. 18851-18866.

Gade, M., V. Byfield, S. Ermakov, O. Lavrova and L. Mitnik 2013. Slicks as Indicators for Marine Processes, Oceanography, 26(2), pp. 138-149.

Gade, M., Mayer, B., Pohlmann, T., Putri, M., and Setiawan, A., 2016. Using SAR Data for a Numerical Assessment of the Indonesian Coastal Environment. Proceedings of the ESA Living Planet Symposium 2016, Prague, Czech Republic.

Jungclaus, J. H., Fischer, N., Haak, H., Lohmann, K., Marotzke, J., Matei, D., Mikolajewicz, U., Notz, D., and von Storch, J. S., 2013. Characteristics of the ocean simulations in the Max Planck Institute Ocean Model (mpiom) the ocean component of the mpi-earth system model. Journal of Advances in Modeling Earth Systems, 5 , pp. 422-446.

Mayer, B., 1995. A threedimensional numerical spm transport model with application to the German Bight (in German). In GKSS Report 95/E/59, GKSS Forschungszentrum Geesthacht $\mathrm{GmbH}$ (Ed.), Geesthacht, Germany.

Mayer, B., and Damm, P.E., 2012. The Makassar Strait throughflow and its jet, Journal of Geophysical Research, 117, C07020, doi:10.1029/2011JC007809.

Mayer, B., Stacke, T., Stottmeister, I., and Pohlmann, T., 2015. Sunda Shelf Seas: flushing rates and residence times. Ocean Science Discussions, 12, pp. 863-895, http://www.ocean-scidiscuss.net/os-2015-28/, doi:10.5194/osd-12-863-201

Meier, C., 2016. Untersuchungen zur Detektion von mariner Ölverschmutzung in indonesischen Seegebieten mit satellitengestützten Radarsensoren. BSc thesis (in German), Universität Hamburg, Institut für Meereskunde.
Sprintall, J., Wijffels, S. E., and Molcard, R., 2009. Direct estimates of the indonesian through?ow entering the indian ocean: 2004-2006. Journal of Geophysical Research, 114 , pp. $1-58$. 